\section{UNUSUAL OCCURRENCE OF A SPRUCE GROUSE}

by Mrs. John Hubbard, Grenfell

On November 18, 1963, a Spruce Grcuse turned up and stayed with us until December 5 when the cats got it-you might say it is still with us! I gave him 24 hours to live when I first saw him because it lived up to its name of "fcol hen". John had his hands on it once and got a good scolding for the indignity. It stayed near the barn and ate green weeds and grasses, and roosted in trees arcund the dugout. Shortly before its demise Jchn saw it escape between the claws of a cat. When seen on December 5 , it had lost its head and the crop was packed with blades of coarse grass of a slough or marsh type. One wonders how this northern bird happened to come here.

This bird was a combination of black, white, and grey, with no browns. The black on the breast was not too extensive and not in a solid mass but it was definitely there. Some of the bird bcoks show solid black on the breast and on the tail, but this was not the case on this bird. Peterson's Field Guide shows a solid chestnut band across the end of the tail; this bird had just the tips of the tail feathers touched with chestnut. I could see nc red comb though I was within 10 feet of the bird and John did not notice it though he was close enough to touch it once. Otherwise this bird fitted the description in the bocks and John knew them from Kelvington days.

Ed. Note: The Spruce Grouse is ordinarily a resident of the Boreal Forest, the nearest points of which may be found at Duck Mountain Prcvincial Park and at Riding Mountain National Park in Manitoba. This implies a movement of at least 100 miles south and west to Grenfell, which lies 70 miles east of Regina. The path of this unusual wanderer was probably along the Qu'Appelle Valley where there is a mcre or less continuous stretch of forest. To our knowledge this is the most scutherly record for this species in Saskatchewan, as well as the deepest penetraration of the Aspen Parkland. C. Stuart Houstcn did not record the pecies though he studied in an area mmediately adjacent to the Boreal forest (1949. The birds of the Yorklon District, Saskatchewan. Can.
Field-Nat., 63:215-241). E. Manley Callin has informed us that he knows of no previous reccrds for the Qu'Appelle Valley area. An occasional southward mcvement within its usual range has been indicated, e.g., J. Dewey Soper notes that a late autumn and winter influx into Riding Mountain from more northern areas appears tc account for the larger winter populaticns (1953. The birds of Riding Mountain National Park, Manitoba, Canada. Widl. Mgt. Bull., Series 2, No. 6. Mimeo., 54 pp. + photos and map).

\section{SIGHT RECORD OF A DIPPER IN SOUTHWESTERN SASKATCHEWAN}

\section{by R. V. Folker, Saskatoon}

H. S. Maliepaard, C. Reid, and I recently observed a bird which I believe was a water cuzel or Dipper (Cinclus mexicanus). Atlhough according to the Peterson Field Guide this bird is an inhabitant of rushing mountain streams, the conditions under which we saw it on October 25, 1963 , on the main street of Maple Creek, were far different. We had just stopped in front cf a cafe when I ncticed a small, gray, seemingly tail-less bird beside the rear wheel of a parked car. I called the attention of the others to the bird and started grcping for my field glasses. Before I located them the bird had been frightened under a car, but it reappeared again for a brief moment before it flew across the street and cut of sight. In that brief interval, I noted that the bird teetered when it moved and suddenly it dawned on me what bird it was. Maliepaard must have recognized it at the same instant for our half-surprised, halfaxcited calls of "dipper!" burst forth almcst simultaneously. We were both familiar with this unique species, he having observed it in Montana, and I in Idaho. Gale force winds which were prevalent in the area during the better part of the week, including the day cf our observation, could acccunt for the unusual appearance of a Dipper on a town street. Records of the Dipper in Saskatchewan are few in number and the species is not yet authenticated by a specimen. All of the records are from the extreme southwestern corner of the province, in and around the Cypress Hills (see Blue Jay, 16:64-65). 